\title{
Determination of synthetic colorants in cosmetic products by reversed-phase high-performance liquid chromatography coupled with diode-array detector
}

\author{
Zeynep FİLIZ ${ }^{1}$ (D) , Tülay OYMAK ${ }^{1}$ (D) , Emrah DURAL ${ }^{2 *}$ (D) \\ 1 Department of Analytical Chemistry, Faculty of Pharmacy, Sivas Cumhuriyet University, Sivas, Turkey. \\ 2 Department of Pharmaceutical Toxicology, Faculty of Pharmacy, Sivas Cumhuriyet University, Sivas, Turkey. \\ * Corresponding Author. E-mail: emrahdural@cumhuriyet.edu.tr (E.D.); Tel. +90-(346)-219 10 10-3920.
}

Received: 26 May 2019 / Revised: 05 October 2019 / Accepted: 06 October 2019

\begin{abstract}
This study aimed at developing and validating a reversed-phase (RP) high-performance liquid chromatography (HPLC) method, for simultaneous determination of five synthetic dyes called tartrazine (TRZ), sunset yellow (SY), allura red AC (AR), brilliant blue FCF (BB) and erythrosine B (EB) in cosmetic samples. The separation was performed by a C18 reverse phase analytical column $(4.6 \times 250 \mathrm{~mm}, 5 \mu \mathrm{m})$ at $30^{\circ} \mathrm{C}$ with gradient elution and the mobile phase contained $20 \mathrm{mM}$ ammonium acetate buffer, acetonitrile and methanol. Flow was $1.0 \mathrm{~mL} / \mathrm{min}$. Detection wavelengths of diode array detector (DAD) were set at 420,480, 510, 634 and $530 \mathrm{~nm}$ for TRZ, SY, AR, BB and EB, respectively. The dyes were analysed in $24 \mathrm{~min}$. The limits of detection (LOD) was $\leq 0.18 \mu \mathrm{g} / \mathrm{mL}$. The recovery was between 88.7 and $103.0 \%$. Precision was $\leq .7 .33$ (RSD \%) and accuracy was $\leq 3.0$ (RE\%). It was determined that 7 different cosmetic samples analyzed, consisting of soap, shower gel, eyeshadow, mouthwash, and lip pencil contained synthetic dyes at a concentration of 0.29 to $10.81 \mathrm{mg} / \mathrm{g}$.
\end{abstract}

KEYWORDS: Synthetic colorants; method validation; HPLC-DAD; cosmetic.

\section{INTRODUCTION}

Colorants, are widely used in foods, cosmetics, beauty supplies, plastics, toys, chemicals, pharmaceuticals, cosmetics and personal care products to increase the appeal of the product to consumers. It is very common to use colorants in consumer products because it makes them more attractive. Coloring agents are added to cosmetic and personal care products formulations to color the product itself or to color the lashes, hair, nails and skin for decorative purposes [1,2].

Nowadays, approximately 10,000 chemical compounds, including organic and inorganic, are being used as coloring agents in the preparation of the main group consumer products [3,4]. These agents are produced from natural substances obtained from plants, animals and minerals [1]. Natural colorants are often unstable, expensive and easily degraded by the influence of light, temperature or changing $\mathrm{pH}$ during the manufacturing process and storage. In addition, natural colorants are not soluble but synthetic colorants are soluble in hydro or oil. Also, synthetic dyes have a lot of important advantages such as higher stability to light, oxygen and $\mathrm{pH}$, low microbiological contamination risk, long-lasting and low price and to color uniformity. Therefore, natural dyes have been partially or completely replaced by synthetic counterparts [5-7].

Synthetic colorants, based on their chemical structure, divided in five main classes: Azo, triarylmethane, xanthene, indigo and quinoline classes and usually used as the water-soluble sodium salts $[1,8]$. Tartrazine (TRZ), sunset yellow (SY), and allura red (AR) are classified as azo group dyes. Brilliant blue (BB) belongs to the triarylmethane group and also erythrosine $\mathrm{B}(\mathrm{EB})$ is classified as a xanthene dye.

The chromophore azo groups can be reduced to the suspected carcinogenic amines under certain conditions [3,4,9]. Many studies have been conducted on mutagenic, genotoxic and carcinogenic effects [1012]. Extensive cytostatic potential, DNA binding properties and reduced mitotic index were observed for TRZ [13]. However in the another study, it was shown that TRZ caused an increase in the mitotic index unrelated to the dose. The genotoxic effects determined were performed on organs such as the colon and stomach of the

How to cite this article: Filiz Z, Oymak T, Dural E. Determination of synthetic colorants in cosmetic products by reversed-phase high-performance liquid chromatography coupled with diode-array detector. J Res Pharm. 2019; 23(6): 1048-1059. 
mouse [14]. TRZ exposure has been shown to cause decreased sperm count and sperm abnormalities [15]. It has been reported by Kemal and El-lethey TRZ exposure causes increased activity, anxiety and anti-social behaviour [16]. In another study, it observed that AR has a direct genotoxic property [17]. Column-specific DNA damage in mice was determined for this dye [18]. The European Food Safety Authority (EFSA) banned AR use in animal feed [19]. It was proven that AR has behavioural effects on humans and animals [20]. The consumption of EB, which could be a significant risk factor in human breast carcinogenesis, and reduced mobility of sperm in mice. The mutagenic effect of EB has been shown in different studies [21-22]. The In vitro genotoxic effect of EB was evaluated [23] and results were proven that, EB is genotoxic.

Also another study aimed to determine the genotoxicity and cytotoxicity of EB and the result showed that EB has cytostatic and genotoxic properties [24]. Sasaki et al. demonstrated that EB caused a DNA damage effect [14]. In an in vitro study a high degree of cytostatic and cytotoxic properties were observed [13]. According to another study, results conducted chronically with EB, showed an increase of some tissue and organ weights [25]. In addition, some studies proved that EB has potentially toxic effects on the reproductive process $[26,27]$.

Synthetic colorants are added to color the cosmetic material or to color the eyelashes, skin, nails, hair, and even decorative powders for cosmetic and personal care product formulations. People are exposed to dermatologically colored agents except oral products. It poses a great challenge to develop reliable analytical methodologies for the quantification of colorant reagents, depending on the variety of chemical structures and the complexity of the matrices containing them $[1,3,4,28]$. Due to their toxicity, especially when consumed in excess, synthetic dyes are strictly controlled by laws, regulations and acceptable daily intake values for food safety [9-11].

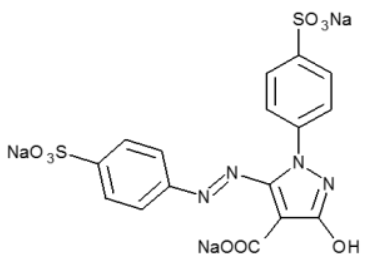

TRZ

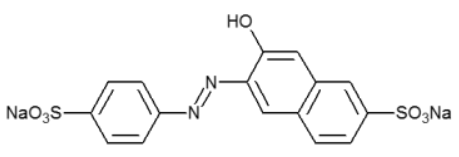<smiles>CCOc1ccc(Nc2ccc(C(=C3C=CC(=[N+](C)Cc4cccc(S(=O)(=O)[O-])c4)C=C3C)c3ccc(N(CC)Cc4cccc(S(C)(=O)=O)c4)cc3C)cc2)cc1</smiles>

BB

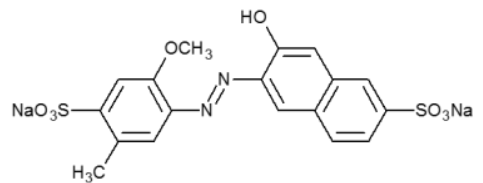

AR

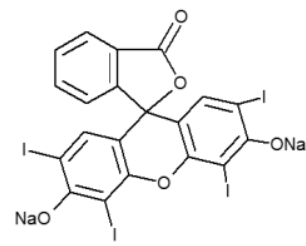

$\mathrm{EB}$

Figure 1. The chemical structures of TRZ, SY, AR, BB and EB.

For this reason, quantitative identification of toxicologically important dyes from real samples by a simple, precise and reliable method is of vital importance. However, due to the often complex matrix of cosmetic products, the sample preparation stage is of great importance. Due to the need for complex techniques, long-term sample preparation processes make routine analysis difficult. At the same time, the analysis of these assays with high-precision analyzers makes regular analysis challenging. For this purpose, various analytical methods such as thin layer chromatography, spectrophotometry, derivative spectrophotometry, fluorimetry, voltammetry, differential pulse polarography, capillary electrophoresis, HPLC and ion chromatography have been used [9,12,31-37].

Spectrophotometric methods have been widely used for determination of these colorants but these methods have involved the relatively low sensitivity values [38]. The separation step is to become a requirement because of the obvious interference from the background caused by other additives [39]. 
Chromatographic separation is known to give very successful results in the quantitative determination of the amount of target dye compounds. Reverse phase liquid chromatography-based methods are commonly preferred in synthetic dye analysis. Conventionally, because of the ability of the colorants to be absorbed in the UV-Vis spectrum, the preferred detector is DAD as recommended [40]. HPLC techniques are well suited for the analysis of samples containing several colorants. These techniques provide high sensitivity and resolution, and allow simultaneous determination of colorants from the sample [11,33-35].

This paper describes a new, sensitive and reliable RP-HPLC method combined with a diode array detector for the simultaneous determination of TRZ, SY, AR, BB and EB in cosmetic samples. This method allows sample preparation without the need for any extraction process. Our suggested method validated according to ICH guidelines [41]. Finally, our recommended method was used for the quantitative determination of synthetic colorants in five cosmetic products. The chemical structures of TRZ, SY, AR, BB and EB are given at Figure 1.

\section{RESULTS AND DISCUSSION}

Optimum analytical conditions were set after the optimization procedure was performed for column selection, the content of the mobile phase and wavelength. The best separation performance was obtained from RP C18 Zorbax (USA) analytical column. The mobile phase flow rate and column oven temperature were set to $1.0 \mathrm{~mL} / \mathrm{min}$ and $30^{\circ} \mathrm{C}$, respectively. The analysis was carried out under gradient conditions that were optimized. DAD was set to 420,480,510, 634 and $530 \mathrm{~nm}$, with the sequential program for the detection of TRZ, SY, AR, BB and EB, respectively. The retention times of TRZ, SY, AR, BB and EB were 8.5, 12.7, 14.4, 17.8 and $23.1 \mathrm{~min}$, respectively. The method was linear, between $0.5-20 \mu \mathrm{g} / \mathrm{mL}$ for all analytes. LOD was found as $\leq 0.13 \mu \mathrm{g} / \mathrm{mL}$ and LOQ was found as $\leq 0.40 \mu \mathrm{g} / \mathrm{mL}$ for all compounds investigated. Determination coefficients $\left(\mathrm{R}^{2}\right)$ were calculated between 0.9985 and 0.9996 . Total run time was $24.0 \mathrm{~min}$.

\subsection{Method validation}

Method was validated to specificity and selectivity, linearity, sensitivity, repeatability and recovery. The validation protocol was performed according to the ICH guideline [41], taking into account the reproducibility of the method to obtain precise and accurate measurements.

\subsubsection{Specificity and selectivity}

There were no unwanted peaks observed in all of the chromatograms of blank samples (Figure 2) Neither peaks nor changes in the structure of the baseline chromatogram was detected, especially at retention times of analytes. No structural degradation was observed in the peaks of chromatograms of standard chemicals. In the analysis of samples, peaks were also very stable in terms of retention time and peak structure. This situation was observed in specificity and selectivity of the method and had a very beneficial effect on the reproducibility of the method.

The DAD set at 420, 480, 510, 634 and $530 \mathrm{~nm}$ was displaying optimum sensitivity for TRZ, SY, AR, BB and EB. The method demonstrated excellent chromatographic specificity with no interference at the retention times of TRZ, SY, AR, BB and EB $(8.5,12.7,14.4,17.8$ and 23.1, respectively). The different retention times of the dyes in the HPLC column had a very positive effect on the selectivity and sensitivity values of the method. Chromatograms of dye standards were given in Figure 3, which shows the high resolution with no interference in relatively short separation time ( $24 \mathrm{~min}$ ) for 5 dyes. Chromatograms of the synthetic dyes which belong to, TRZ (8.5 min), SY (12.7 min), AR (14.4 min), BB (17.8 min) and EB (23.1 min), according to retention times are shown in Figure 3.

\subsubsection{Linearity}

Calibration curves of the analytes were plotted with the standard addition method and the response of each calibration point was determined by the response of the 3 individual samples. The calibration points were determined as $0.5,1,2,5,10$ and $20 \mu \mathrm{g} / \mathrm{mL}$ for all colorants. The determination coefficient $\left(\mathrm{R}^{2}\right)$ for all dyes was calculated as above $0.998(\mathrm{n}=3)$. Results are given in Table 1 .

\subsubsection{Sensitivity}

The limit of detection (LOD) and quantification (LOQ) based on the standard deviation of the response and the slopes of the calibration graphs, were calculated according to the $\mathrm{ICH}$ recommendations $\mathrm{LOD}=3.3 \mathrm{\sigma} / \mathrm{S}$; 
$\mathrm{LOQ}=10 \sigma / \mathrm{S}$ ( $\sigma$ : The standard deviation of the response; S: calibration curve slope). $0.5 \mu \mathrm{g} / \mathrm{mL}$ concentration of analytes were used to the calculation of LOD and LOQ.
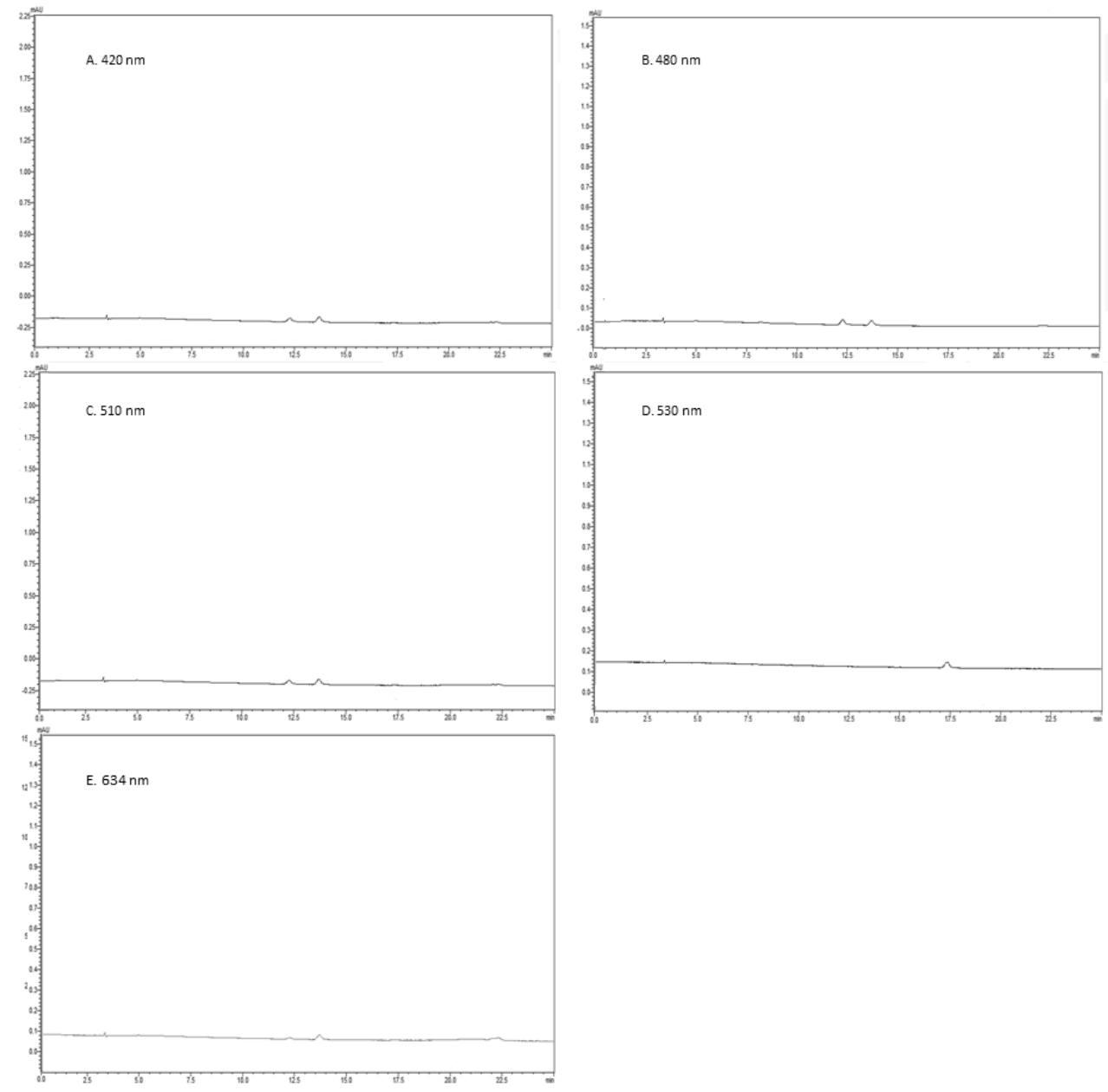

Figure 2. Blank chromatograms of synthetic dyes obtained at their specific wavelengths. A. TRZ, B. SY, C. $\mathrm{AR}, \mathrm{D}$. EB and E. BB, according to retention times.

As shown in Table 1, LOD values were calculated as between $0.13 \mu \mathrm{g} / \mathrm{mL}$ and $0.16 \mu \mathrm{g} / \mathrm{mL}$ in all dyes. Also, it was calculated that LOQ values were between $0.40 \mu \mathrm{g} / \mathrm{mL}$ and $0.53 \mu \mathrm{g} / \mathrm{mL}$. These sensitivity results were very important for the quantitative determination of low amounts of dyes in cosmetic samples. For example, it was detected $0.29 \pm 0.03 \mu \mathrm{g} / \mathrm{g}$ concentration of TRZ in the soap sample was detected as the lowest analyte concentration. Also, AR was determined in mouthwash sample as $0.5 \pm 0.005 \mu \mathrm{g} / \mathrm{g}$ concentration.

\subsubsection{Accuracy and precision}

Accuracy, expressed as the relative error (RE\%), was also determined for the same concentrations of analytes. Precision, defined as relative standard deviation (RSD), was determined by five individual replicates at three different concentrations $(n=5)$. It is the degree of veracity while precision is the degree of reproducibility. Table 2 shows the RSD and RE\% values of the method that indicates inter- and intra-day of precision and accuracy values of low, medium and high concentrations of analytes. Results are given in Table 2.

The intraday precision was between 0.79 and 4.69 (RSD). The inter-day precision values were between 0.57 and 7.33. It was found that the inter-day precision values generally showed higher deviation values than the intra-day values. This method shows that the accuracy obtained during the intra-day is higher than the accuracy inter-day. This result is an expected situation in validation studies. It has also been observed that the deviation in inter-day precision values is mainly due to the high deviation in the highest concentrations of TRZ, AR and BB. 

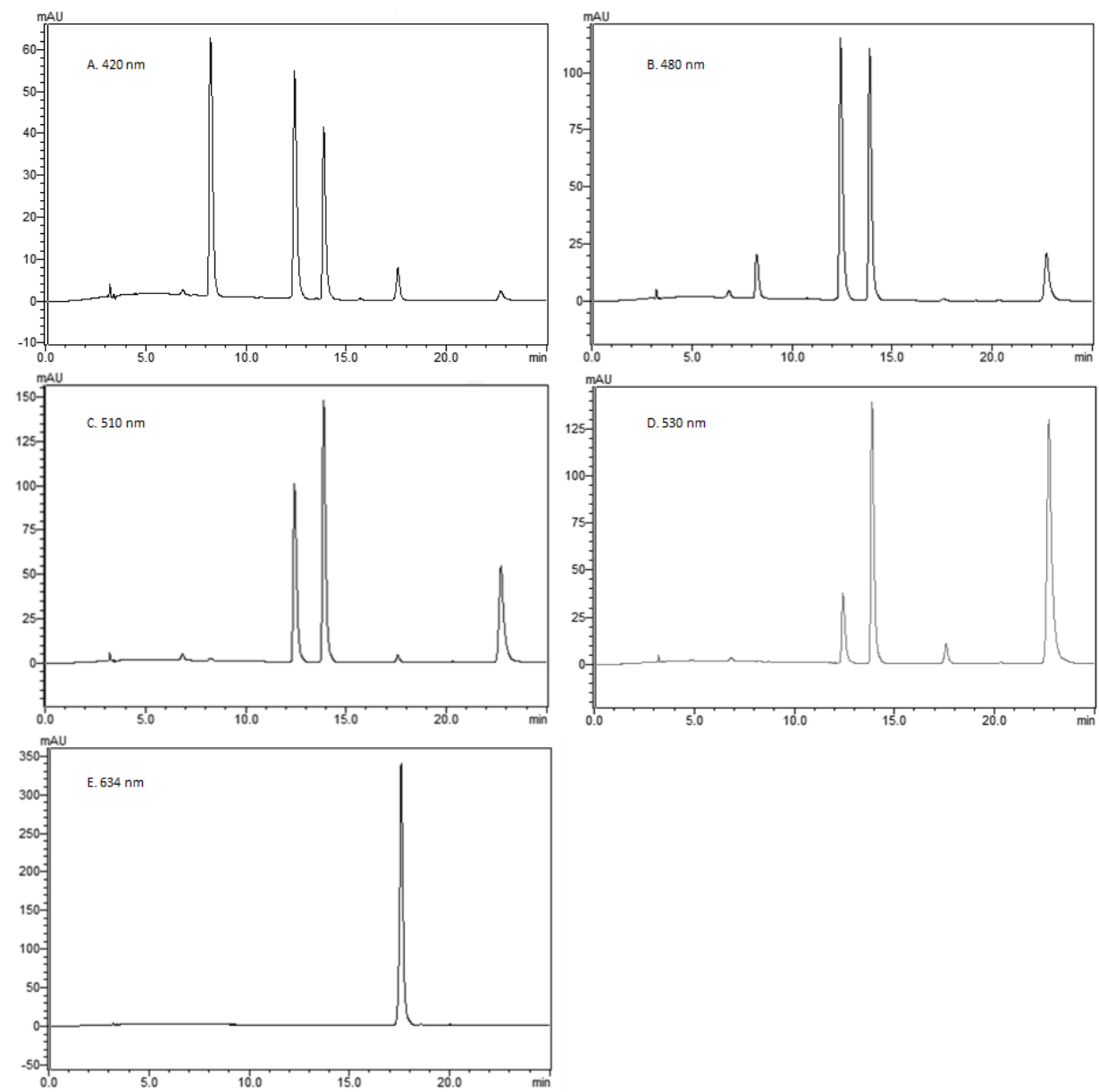

Figure 3. Chromatograms of the synthetic dyes; A. TRZ (8.5 min), B. SY (12.7 min), C. AR (14.4 min), D. EB (23.1 $\mathrm{min})$ and E. BB (17.8 $\mathrm{min})$.

Table 1. Chromatographic characteristics and system suitability parameters of the method for the HPLCDAD analysis of dyes.

\begin{tabular}{cccccccccc}
\hline Colorant & $\lambda(\mathrm{nm})$ & $\mathbf{t}_{\mathbf{R}}(\mathrm{min})$ & $\begin{array}{c}\text { LOD } \\
(\mu \mathrm{g} / \mathrm{mL})\end{array}$ & $\begin{array}{c}\text { LOQ } \\
(\mu \mathrm{g} / \mathrm{mL})\end{array}$ & $\begin{array}{c}\text { Linear } \\
\text { Range }\end{array}$ & Calibration equation & $\mathbf{R}^{2}$ & $\mathbf{k}^{\prime}$ & $\mathbf{N}$ \\
\hline TRZ & 420 & 8.5 & 0.18 & 0.53 & $0.5-20$ & $\mathrm{y}=36011.23 x+1798.7$ & 0.9992 & 1.6 & 26876 \\
$\mathrm{SY}$ & 480 & 12.7 & 0.13 & 0.40 & $0.5-20$ & $\mathrm{y}=643504 x+2898.6$ & 0.9988 & 2.8 & 7942 \\
$\mathrm{AR}$ & 510 & 14.4 & 0.16 & 0.47 & $0.5-20$ & $\mathrm{y}=70737.1 \mathrm{x}+12352.6$ & 0.9993 & 3.3 & 3691 \\
$\mathrm{BB}$ & 634 & 17.8 & 0.17 & 0.50 & $0.5-20$ & $\mathrm{y}=197946 \mathrm{x}-29391.7$ & 0.9996 & 4.4 & 7491 \\
$\mathrm{~EB}$ & 530 & 23.1 & 0.13 & 0.40 & $0.5-20$ & $\mathrm{y}=113545 \mathrm{x}-20867.4$ & 0.9985 & 5.9 & 12232 \\
\hline
\end{tabular}

Abbreviations: TRZ: tartrazine, SY: sunset yellow, AR: allura red, BB: brilliant blue, EB: erythrosine $B, \lambda$ : wavelength, $t_{R}$ : time of retention, LOD: Limit of detection, LOQ: limit of quantitation, $\mathrm{R}^{2}$ : determination coefficient, $\mathrm{k}^{\prime}$ : capacity factor, $\mathrm{N}$ : theoretical plate numbers.

The intraday accuracy was between 0.00 and 3.00 (RE\%). Inter-day accuracy was between -1.00 and 3.00. Intra-day accuracy values were found to be less deviated than between days. The result obtained is again an expected result in validation studies. 


\subsubsection{Recovery}

Recovery tests were performed at 1 and $2 \mu \mathrm{g} / \mathrm{mL}$ concentrations of the analytes. The known concentrations of the analytes were added to the samples in appropriate conditions and these analytes were calculated quantitatively by the method. The method recovery was calculated by comparing the observed and expected results. Recovery results are given in Table 3.

The average recoveries were calculated as $100.5 \%, 99.2 \%, 92.9 \%, 95.5 \%$ and $102.9 \%$ for TRZ, SY, AR, BB and EB, respectively. These results were very important for repeatability and sensitivity of the method. The method recovery test was carried out especially in the lowest concentrations of the analytes to demonstrate the method sensitivity.

Table 2. Confidence parameters of method; intra-day and inter-day precision and accuracy for determination of colorants $(n=3)$.

\begin{tabular}{|c|c|c|c|c|c|c|c|}
\hline \multirow[b]{2}{*}{ Colorant } & \multirow[b]{2}{*}{$\begin{array}{l}\text { Added } \\
\text { conc. } \\
(\mu \mathrm{g} / \mathrm{mL})\end{array}$} & \multicolumn{3}{|c|}{ Intra-day } & \multicolumn{3}{|c|}{ Inter-day } \\
\hline & & $\begin{array}{c}\text { Found conc. } \\
\bar{x} \pm \mathrm{SD} \\
(\mu \mathrm{g} / \mathrm{mL})\end{array}$ & $\begin{array}{l}\text { Precision } \\
\text { (RSD) }\end{array}$ & $\begin{array}{c}\text { Accuracy } \\
(\text { RE\%) }\end{array}$ & $\begin{array}{c}\text { Found conc. } \\
\bar{x} \pm S D \\
(\mu \mathrm{g} / \mathrm{mL})\end{array}$ & $\begin{array}{l}\text { Precision } \\
\text { (RSD) }\end{array}$ & $\begin{array}{c}\text { Accuracy } \\
\text { (RE\%) }\end{array}$ \\
\hline \multirow{3}{*}{ TRZ } & 2 & $2.04 \pm 0.06$ & 3.1 & 1.9 & $2.06 \pm 0.04$ & 2.0 & 3.0 \\
\hline & 5 & $5.12 \pm 0.04$ & 0.8 & 2.5 & $5.15 \pm 0.09$ & 1.7 & 3.0 \\
\hline & 10 & $9.97 \pm 0.3$ & 3.0 & 0.3 & $10.02 \pm 0.5$ & 5.0 & 0.2 \\
\hline \multirow{3}{*}{ SY } & 2 & $2.1 \pm 0.04$ & 2.0 & 3.0 & $2.04 \pm 0.01$ & 0.6 & 2.0 \\
\hline & 5 & $5.1 \pm 0.2$ & 4.0 & 2.3 & $5.11 \pm 0.13$ & 2.6 & 2.2 \\
\hline & 10 & $10.0 \pm 0.3$ & 2.9 & 0.4 & $9.94 \pm 0.28$ & 2.8 & -0.6 \\
\hline \multirow{3}{*}{$\mathrm{AR}$} & 2 & $2.1 \pm 0.04$ & 2.0 & 3.0 & $2.04 \pm 0.04$ & 2.0 & 2.0 \\
\hline & 5 & $5.09 \pm 0.06$ & 1.6 & 1.8 & $5.05 \pm 0.04$ & 0.8 & 1.0 \\
\hline & 10 & $10.26 \pm 0.27$ & 2.6 & 2.6 & $9.90 \pm 0.32$ & 3.25 & -1.0 \\
\hline \multirow{3}{*}{$\mathrm{BB}$} & 2 & $2.03 \pm 0.09$ & 4.4 & 1.4 & $2.04 \pm 0.05$ & 2.5 & 2.0 \\
\hline & 5 & $5.01 \pm 0.06$ & 1.2 & 0.2 & $5.05 \pm 0.04$ & 0.8 & 1.0 \\
\hline & 10 & $9.85 \pm 0.46$ & 4.7 & 1.6 & $10.09 \pm 0.74$ & 7.3 & 0.9 \\
\hline \multirow{3}{*}{ EB } & 2 & $2.06 \pm 0.02$ & 1.1 & 3.0 & $2.02 \pm 0.04$ & 3.0 & 1.0 \\
\hline & 5 & $5.00 \pm 0.12$ & 2.5 & 0.0 & $5.06 \pm 0.16$ & 2.4 & 1.2 \\
\hline & 10 & $9.94 \pm 0.31$ & 3.1 & 0.6 & $10.05 \pm 0.48$ & 1.4 & 0.5 \\
\hline
\end{tabular}

Abbreviations: conc: concentration, $\bar{x}$ : average of values, SD: standart deviation, RSD: relative standard deviation, $\mathrm{RE} \%$ : relative error percentage

As the developed method did not involve any extraction method, it is defined as direct analysis. The simple and fast sample preparation phase avoids time loss in the analyzes and allows multiple analyzes to take place within a reasonable time.

Iammarino et al. suggests that in order to investigate 12 food dyes in meat products, a new HPLC method is required. Total analysis time of this method was 43 minutes [12]. The separation was achieved with RP-C18 $150 \times 4.6 \mathrm{~mm}$ analytical column and the quantification of analytes was to be performed with DAD detector set at $520 \mathrm{~nm}$. As a mobile phase, $0.02 \mathrm{M}$ acetate buffer and acetonitrile were applied to the column gradiently. AR and EB were detected with this method at 17 and 23 mins, respectively. The precision values for AR and EB were 11.0 and $15.0 \%$. The result of the recovery test which were performed at 25, 50 and 100 $\mu \mathrm{g} / \mathrm{kg}$ concentrations was between $89-93 \%$ [12]. In a study performed by de Andrade et al., in order to determine concentrations of food dyes in soft drinks, there was two different methods, which are based on TLC and HPLC [10]. Dye identification was performed by the TLC method and quantitation was achieved with the ion pair-HPLC method. Retention times of SY and BB were 14 and $14.5 \mathrm{~min}$, respectively. Analytes were extracted in drinks with the $\mathrm{C} 18$ solid phase technique. The correlation coefficients of the method were $\geq 0.999$ and quantitation limits were $\geq 0.012$. $\mu \mathrm{g} / \mathrm{mL}$. Methanol, water and ammonium acetate, which are used as a mobile phase, were applied to the RP-C18 column with isocratic elution. Recovery was determined between $81-101 \%$. Mathiyalagan et al., developed a new HPLC-UV method. TRZ, SY and BB were determined 
at 2.2, 4.4, 7.7 mins in this method [9]. The liquid-liquid extraction technique was used to obtane dyes from the samples. Ethanol, hexane, butylated hydroxytoluene, water and ammonia solution were used as extraction solvents. Recovery was found between 90 and $97 \%$. LOQ was $\geq 15.1 \mathrm{ng} / \mathrm{mL}$ and the linearity range was between 10 and $100 \mathrm{ng} / \mathrm{mL}$. The correlation coefficient was $\geq 0.998$. In the method developed by Minioti et al, retention times of TRZ, SY, AR, BB, EB were 11, 16.9, 19.1, 24.8, and 29 minutes, respectively [8]. LOD of the method was between 1.59 and $22.1 \mathrm{ng} / \mathrm{mL}$. The intraday precision was found between 0.37 and $4.8 \%$ and the inter-day precision was observed between 0.86 and $10.0 \%$. The recovery values were between 94 and $102 \%$. A study by Vlase et al. showed, a new HPLC-UV method was developed for determination of 9 water soluble dyes [7]. This method's run time was 8 mins and linearity was between 0.9982 and 0.9997 . LOQ was $\geq 50.1$ $\mathrm{ng} / \mathrm{mL}$. Research from Qin et al. demonstrated, the correlation coefficients $\left(\mathrm{R}^{2}\right)$ of TRZ, SY and AR were calculated $\geq 0.9973$ and this developed method was linear between $0.45-1000.0 \mathrm{ng} / \mathrm{mL}$ [11]. The limit of detection was between $0.60-0.80 \mathrm{ng} / \mathrm{mL}$. Intra-day and inter-day precision was found as 1.72-3.64 and $1.45-$ $1.55 \%$. The analytes were spiked at concentrations of 20,50 and $200 \mathrm{ng} / \mathrm{mL}$ for all 3 dyes. The recovery test was applied at three concentration levels. Recovery was between 80.6 and $116.8 \%$. In the research by Brazeau, the determination of 26 dyes were investigated [35]. TRZ, SY, AR, EB and BB linearity test studies of this method were applied between $0.025 \mu \mathrm{g} / \mathrm{mL}$ and $50 \mu \mathrm{g} / \mathrm{mL}$ concentrations. $R^{2}$ values for the calibration curves were above 0.998 . LOQ levels were detected as between 0.23 and $0.45 \mu \mathrm{g} / \mathrm{g}$.

Table 3. The recovery values of all dyes in the cosmetic samples $(n=3)$.

\begin{tabular}{cccc}
\hline Colorants & Added $(\mu \mathrm{g} / \mathrm{mL})$ & Found $^{\mathrm{a}}(\mu \mathrm{g} / \mathrm{mL})$ & Recovery $\%$ \\
\hline \multirow{3}{*}{ TRZ } & 0 & $\mathrm{nd}^{\mathrm{b}}$ & - \\
& 1 & $1.00 \pm 0.01$ & $99.7 \pm 0.9$ \\
& 2 & $2.02 \pm 0.01$ & $101.2 \pm 0.6$ \\
\hline \multirow{2}{*}{ SY } & 0 & $\mathrm{nd}^{\mathrm{b}}$ & - \\
& 1 & $0.99 \pm 0.01$ & $98.7 \pm 1.3$ \\
& 2 & $1.99 \pm 0.01$ & $99.7 \pm 0.6$ \\
\hline \multirow{3}{*}{ AR } & 0 & $n d^{\mathrm{b}}$ & - \\
& 1 & $0.89 \pm 0.01$ & $88.7 \pm 0.9$ \\
& 2 & $1.94 \pm 0.05$ & $97.0 \pm 2.5$ \\
\hline \multirow{3}{*}{ BB } & 0 & $0.81 \pm 0.05$ & \\
& 1 & $1.70 \pm 0.01$ & $95.0 \pm 1.0$ \\
& 2 & $1.91 \pm 0.03$ & $96.0 \pm 1.0$ \\
\hline \multirow{2}{*}{ EB } & 0 & $\mathrm{nd}$ & - \\
& 1 & $1.03 \pm 0.03$ & $102.7 \pm 3.3$ \\
& 2 & $2.07 \pm 0.04$ & $103.0 \pm 1.9$ \\
\hline
\end{tabular}

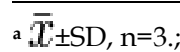

b nd: not detected.

The correlation coefficient value of the proposed method is $\geq 0.998$ which is comparable to the literature. Precision test results were 0.79 and 4.69 (RSD) inra-day and 0.57 and 7.33 for inter-day analysis. The precision values of Iammarino et al. [12], Minioti et al, [8] and Mathiyalagan et al., [9] ranged from 10.0 to 15.0 RSD\%. It is clear that the suggested method's accuracy results are comparible with the literature and there are not too many deviations that may result in negative effects on the sample analysis. Our accuracy test results were between -1.00 and 3.00 (RE\%) for intra-day and interday. These accuracy values are considered as sufficient for safe analysis. When the literature is examined, it is seen that the recovery values of dye analysis methods vary between 80.6 and $116 \%$ [7-10, 12, 35]. The recovery values of our method are between 92.9 and $102.9 \%$. These recovery values indicate that the method can safely perform sample analyzes. The sensitivity values of our method, measured with LOQ values were between 0.13 and $0.16 \mu \mathrm{g} / \mathrm{mL}$. Although this value is higher than the study reported by Brazeau (35), other studies with higher sensitivity have been observed in the literature. In our study, where the analysis time was 24 minutes, the distinction was very strong. The retention times of the analytes are suitable for use in the laboratory for routine sample monitoring. 


\subsection{Analysis of the colorants in real samples}

The accuracy of the described method was evaluated analyzing spiked samples. For this, dyes in various concentrations were added to the eyeshadow $(0.10 \mathrm{~g})$ samples and then the described method was applied. Three parallel analyses were performed for each concentration level. As can be seen from Table 3, the recoveries are found to be satisfactory for cosmetic samples.

Our proposed method was successfully applied to the real cosmetic samples such as soap, shower gels, eye shadows, mouthwash and lip pencil. Different types of samples which had different matrices did not cause any adverse effects on the chromatograms and no interference was observed. $10 \mathrm{mg}, 50 \mathrm{mg}$ and $1 \mathrm{~g}$ of liquid or solid sample was dissolved in $5 \mathrm{~mL}$ of a water-methanol mixture separately and was mixed using a sonicator for 1 hour at $60^{\circ} \mathrm{C}$. There was not any extraction application in this method. Also samples were prepared at the end of the sonication process. After the filtration implementation, clear residual was implemented to the HPLC as $20 \mu \mathrm{L}$. All of the sample preparation process was simple, time saving, and it did not need any complicated instrument so is reproducible in many laboratories. Total liquid volume used in the sample preparation process was $5 \mathrm{~mL}$ of the water-methanol mixture $(1: 1, \mathrm{v} / \mathrm{v})$. For this reason, it could be evaluated as an environmentally friendly analytic method considering the sample preparation phase. The total analysis time was $30 \mathrm{~min}$ as each analysis took $24 \mathrm{~min}$ and column reconditioning took $6 \mathrm{~min}$. Also, since the method does not need to any extraction application and the sample was applied to the column directly, the chromatographic analysis time it needs was an acceptable length. Sample chromatograms were given in Figure 4 .

When the dye levels in the samples were examined, an unexpected level of SY $(10.81 \mu \mathrm{g} / \mathrm{mL} \pm 0.68)$ was detected in sample-4, eye-shadow. During the analysis of this sample, it was observed that the analyte peak was very clear and the structure was very sharp. During the analysis, no carry over" which could have a negative effect on the next analysis was not performed. A significant amount of excess TRZ $(1.9 \mu \mathrm{g} / \mathrm{mL} \pm$ 0.26) was detected in Sample 2, shower gel. The chromatogram and peak structure obtained during the analysis were well suited for repeated analysis.

Table 4. The colorant results obtained in the real cosmetic samples.

\begin{tabular}{cccc}
\hline $\begin{array}{c}\text { Sample } \\
\text { number }\end{array}$ & Sample type & $\begin{array}{c}\text { Detected } \\
\text { colorants }\end{array}$ & $\begin{array}{c}\text { Content of } \\
\text { colorant } \mathbf{~}^{\mathbf{m g} / \mathbf{g})}\end{array}$ \\
\hline $\mathbf{1}$ & Soap & TRZ & $0.29 \pm 0.03$ \\
$\mathbf{2}$ & Shower gel 1 & TRZ & $1.9 \pm 0.26$ \\
$\mathbf{3}$ & Shower gel 2 & SY & $1.2 \pm 0.07$ \\
$\mathbf{4}$ & Eyeshadow 1 & SY & $10.81 \pm 0.68$ \\
$\mathbf{5}$ & Eyeshadow 2 & BB & $0.71 \pm 0.02$ \\
$\mathbf{6}$ & Mouthwash & AR & $0.5 \pm 0.005$ \\
$\mathbf{7}$ & Lip pencil & EB & $1.38 \pm 0.12$ \\
\hline a $\bar{x}+\mathrm{SD}, \mathrm{n}=3$ & & &
\end{tabular}

\section{CONCLUSION}

We recommended this optimized and validated reversed-phase HPLC coupled with DAD method to be used in simultaneous analysis of TRZ, SY, AR, BB and EB in cosmetic products. This method has significant advantages such as; direct analysis, environmentally-friendly and low-cost. The application does not require complex tools for the determination of the five dyes. The method can be easily modified and applied for the routine analysis of synthetic dyes in toxicologically reference laboratories and food analysis and control laboratories. Also, this method is suggested for colourant analysis in many types of materials in the toxicological analysis laboratory. Method validation results showed good sensitivity and recovery values. Also, precision and accuracy test results obtained from the repeatability tests were very significant. The method could be used for many kind of cosmetics and it can be adapted for monitoring of other consumer products such as foods and drinks. The method can also be used in environmental pollution studies involving the monitoring of dyes from environmental-biological media. In addition, it may be considered that the method may have limited ability to analyze, especially in cosmetic products containing a much more complex matrix. Here, the absence of any extraction application is the main factor. 

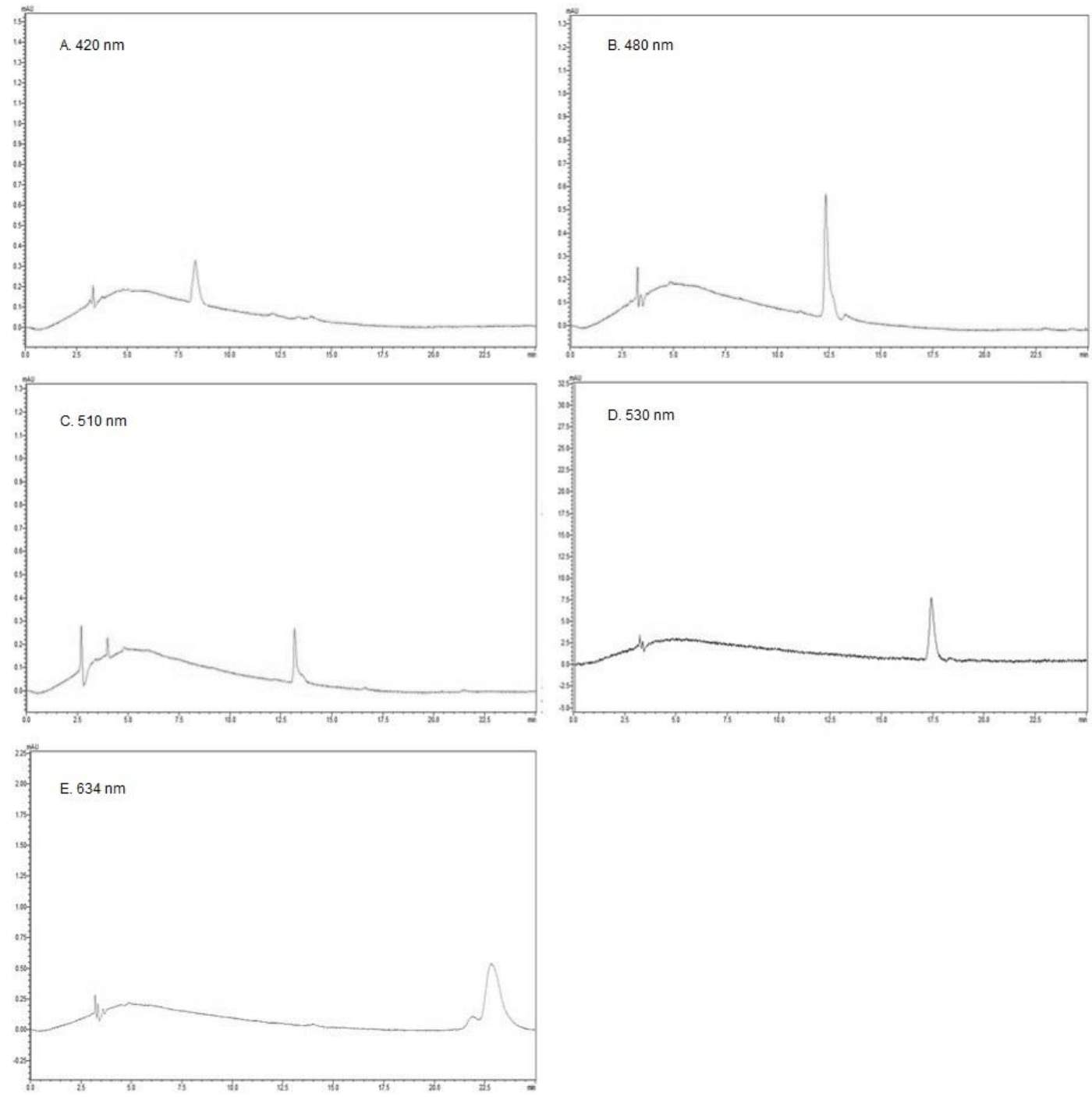

Figure 4. Sample chromatograms which belong to sample of 1(A), 3(B), 5(E), 6(C) and 7(D) which are soap, shower gel, eye shadow, mouthwash and lip pencil, respectively. The numbers 1, 3, 5, 6 and 7 represent the sample numbers given in Table 4 .

\section{MATERIALS AND METHODS}

\subsection{Chemicals and reagents}

The analytical standard of SY (E110), AR (E129), BB (E133) and EB (E127), obtained from Sigma-Aldrich (Massachusetts, USA) and TRZ (E102) were ordered from Alfa Easer (Kandel, Germany). The HPLC grade acetonitrile and methanol and also the analytical grade ammonium acetate was purchased from Sigma-Aldrich (Missouri, USA). The Elga Purelab Water Purification System (Buckinghamshire, United Kingdom) was used to obtain ultrapure water.

\subsection{Instrument and chromatographic conditions}

Shimadzu LC-20AD HPLC system (Kyoto, Japan) equipped with a degasser (DGU-20A5R), an automatic liquid sampler (SIL-20ACHT) have a $20 \mu \mathrm{L}$ sample loop volume, a column oven (CTO-10AS) and a DAD (SPD-M20A) was used for chromatographic separation and quantification. A reverse phase C18 analytical column (250 x $4.6 \mathrm{~mm}$ i.d., $5 \mu \mathrm{m}$ p.s.) Zorbax (USA) was used for separation. Ammonium acetate buffer, acetonitrile and methanol were used as the mobile phase. Mobile phase A was prepared with $20 \mu \mathrm{M}$ ammonium acetate buffer ( $\mathrm{pH}$ : 6.7) and it was degassed over the 30 minutes by the sonicator that before each analysis. Mobile phase B was prepared with methanol and acetonitrile (1:1, v/v). DAD was set to 420 , 480 , 510, 634 and $530 \mathrm{~nm}$, with the sequential program for the detection of TRZ, SY, AR, BB and EB, respectively. 
The analysis was carried out under gradient condition using $1.0 \mathrm{~mL} / \mathrm{min}$ flow rate at $30^{\circ} \mathrm{C}$. The gradient mobile phase flow program was as follows: The initially mobile phases flow ratio is $97: 3,(\mathrm{v} / \mathrm{v})$ for mobile phase A and B. Then mobile phase ratios linearly changed to 40:60, (v/v) over 18 mins. This elution ratio is held over 6 mins. The total run time was 24 minutes.

\subsection{Preparation of stock solutions and working standards}

The stock solutions of $100 \mathrm{mg} / \mathrm{L}$ TRZ, SY, AR, BB and EB were prepared by dissolving in deionized water and stored at $+4{ }^{\circ} \mathrm{C}$. The main stocks and working solutions were chemically stable at $+4^{\circ} \mathrm{C}$ for at least 1 month. The calibration standards and quality control samples were prepared by the serial dilution from the working solutions with the mixture of methanol: water $(1: 1, \mathrm{v} / \mathrm{v})$.

\subsection{Collection of cosmetic samples}

Cosmetic samples were purchased from the different markets located in Sivas, Turkey and were stored at room temperature until analysis. All of the samples were analyzed before the expiry date of the shelf life.

\subsection{Sample preparation}

$10 \mathrm{mg}$ of lip pencil and eyeshadow, $50 \mathrm{mg}$ of soap, $1 \mathrm{~g}$ of shower gel were dissolved in $5 \mathrm{~mL}$ of the water-methanol mixture $(1: 1, \mathrm{v} / \mathrm{v})$ by the ultrasonic bath at $60^{\circ} \mathrm{C}$ for 1 hour. The mouthwash was diluted with the water-methanol mixture $(1: 1, \mathrm{v} / \mathrm{v})$ by the $1 / 2$ ratio. The dissolved sample was filtered with a $0.45 \mu \mathrm{m}$ filter. Finally, $20 \mu \mathrm{L}$ clear sample was loaded to the HPLC. The analysis of the samples was performed in three replicates.

Acknowledgements: This research was supported by Sivas Cumhuriyet University under the Faculty of Pharmacy Student Research and Support Programme.

Author contributions: Concept - T.O. E.D.; Design - T.O., E.D.; Supervision - T.O., E.D.; Resource - T.O., E.D.; Materials - T.O., Z.F.; Data Collection and/or Processing - T.O., E.D., Z.F.; Analysis and/or Interpretation - T.O., Z.F., E.D.; Literature Search - T.O., E.D.; Writing - T.O., E.D.; Critical Reviews - T.O., E.D., Z.F.

Conflict of interest statement: None of the authors of this article has a financial or personal relationship with other persons or organizations that may inappropriately affect or bias the content of the paper. The authors declare that there are not any conflict of interests.

\section{REFERENCES}

[1] Lores M, Llompart M, Alvarez-Rivera G, Guerra E, Vila M, Celeiro M, Lamas JP, Garcia-Jares C. Positive lists of cosmetic ingredients: Analytical methodology for regulatory and safety control - A review. Anal Chim Acta. 2016; 915: 1-26. [CrossRef]

[2] Lee M, Nam KT, Kim J, Lim SE, Yeon SH, Lee B, Lee JY, Lim KM. Evaluation of ocular irritancy of coal-tar dyes used in cosmetics employing reconstructed human cornea-like epithelium and short time exposure tests. Food Chem Toxicol. 2017; 108: 236-243. [CrossRef]

[3] Guerra E, Alvarez-Rivera G, Llompart M, Garcia-Jares C. Simultaneous determination of preservatives and synthetic dyes in cosmetics by single-step vortex extraction and clean-up followed by liquid chromatography coupled to tandem mass spectrometry. Talanta. 2018; 188: 251-258. [CrossRef]

[4] Guerra E, Celeiro M, Lamas JP, Llompart M, Garcia-Jares C. Determination of dyes in cosmetic products by micromatrix solid phase dispersion and liquid chromatography coupled to tandem mass spectrometry. J Chromatogr A. 2015; 1415: 27-37. [CrossRef]

[5] Allam KV, Kumar GP. Colorants - the cosmetics for the pharmaceutical dosage forms. Int J Pharm Pharm Sci. 2011; 3(3): 13-21.

[6] de Boer L. Biotechnological production of colorants. In: Zorn H, Czermak P. (Eds) Biotechnology of Food and Feed Additives. Advances in Biochemical Engineering/Biotechnology 143, Springer, Berlin, 2013, pp.51-89. [CrossRef]

[7] Vlase L, Muntean D, Codruta CS, Lorena F. Development and validation of an HPLC UV method for determination of synthetic food colorants. Rev Roum Chim. 2014; 59(9): 719-725.

[8] Minioti KS, Sakellariou CF, Thomaidis NS. Determination of 13 synthetic food colorants in water-soluble foods by reversed-phase high-performance liquid chromatography coupled with diode-array detector. Anal Chim Acta. 2007; 
583(1): 103-110. [CrossRef]

[9] Mathiyalagan S, Mandal BK, Ling YC. Determination of synthetic and natural colorants in selected green colored foodstuffs through reverse phase-high performance liquid chromatography. Food Chem. 2019; 278: $381-387$. [CrossRef]

[10] de Andrade FI, Florindo Guedes MI, Pinto Vieira ÍG, Pereira Mendes FN, Salmito Rodrigues PA, Costa Maia CS, Marques Avila MM, De Matos Ribeiro L. Determination of synthetic food dyes in commercial soft drinks by TLC and ion-pair HPLC. Food Chem. 2014; 157: 193-198. [CrossRef]

[11] Qin P, Yang Y, Li W, Zhang J, Zhou Q, Lu M. Amino-functionalized mesoporous silica nanospheres $\left(\mathrm{MSN}^{\left.-\mathrm{NH}_{2}\right)}\right.$ as sorbent for extraction and concentration of synthetic dyes from foodstuffs prior to HPLC analysis. Anal Methods. 2019; 11(1): 105-112. [CrossRef]

[12] Iammarino M, Mentana A, Centonze D, Palermo C, Mangiacotti M, Chiaravalle AE. Simultaneous determination of twelve dyes in meat products: Development and validation of an analytical method based on HPLC-UV-diode array detection. Food Chem. 2019; 285: 1-9. [CrossRef]

[13] Mpountoukas P, Pantazaki A, Kostareli E, Christodoulou P, Kareli D, Poliliou S, Mourelatos C, Lambropoulou V, Lialiaris T. Cytogenetic evaluation and DNA interaction studies of the food colorants amaranth, erythrosine and tartrazine. Food Chem Toxicol. 2010; 48(10): 2934-2944. [CrossRef]

[14] Sasaki YF, Sekihashi K, Izumiyama F, Nishidate E, Saga A, Ishida K, Tsuda S. The comet assay with multiple mouse organs: comparison of comet assay results and carcinogenicity with 208 chemicals selected from the IARC monographs and U.S. NTP Carcinogenicity Database. Crit Rev Toxicol. 2000; 30(6): 629-799. [CrossRef]

[15] Mehedi N, Ainad-Tabet S, Mokrane N, Addou S, Zaoui C, Kheroua O, Saidi D. Reproductive toxicology of tartrazine (FD and C Yellow No. 5) in Swiss Albino Mice. Am J Pharmacol Toxicol. 2009; 4(4): 130-135. [CrossRef]

[16] Kamel MM, El-Lethey HS. The potential health hazard of tartrazine and levels of hyperactivity, anxiety-like symptoms, depression and anti-social behaviour in rats. J Am Sci. 2011; 7(6): 1211-1218.

[17] Jabeen HS, ur Rahman S, Mahmood S, Anwer S. Genotoxicity assessment of amaranth and allura red using Saccharomyces cerevisiae. Bull Environ Contam Toxicol. 2013; 90(1): 22-26. [CrossRef]

[18] Shimada C, Kano K, Sasaki YF, Sato I, Tsudua S. Differential colon DNA damage induced by azo food additives between rats and mice. J Toxicol Sci. 2010; 35(4): 547-554. [CrossRef]

[19] EFSA, 2012c, Scientific opinion on the safety and efficacy of Allura Red AC (E129) in feed for cats and dogs. EFSA J. 2012; 10(5): 2675. [CrossRef]

[20] Rovina K, Siddiquee S, Shaarani SM. Extraction, analytical and advanced methods for detection of allura red AC (E129) in food and beverages products. Front. Microbiol. 2016; 27(7): 798. [CrossRef]

[21] Lakdawalla AA, Netrawali MS. Mutagenicity, comutagenicity, and antimutagenicity of erythrosine (FD and C red 3), a food dye, in the Ames/Salmonella assay. Mutat Res. 1988; 204(2): 131-139. [CrossRef]

[22] Matula TI, Downie RH. Genetic toxicity of erythrosine in yeast. Mutat Res. 1984; 138(2-3): 153-156. [CrossRef]

[23] Chequer FM, Venâncio VP, Bianchi ML, Antunes LM. Genotoxic and mutagenic effects of erythrosine B, a xanthene food dye, on HepG2 cells. Food Chem Toxicol. 2012; 50(10): 3447-3451. [CrossRef]

[24] Rogers CG, Boyes BG, Matula TI, Héroux-Metcalf C, Clayson DB. A case report: A multiple end-point approach to evaluation of cytotoxicity and genotoxicity of erythrosine (FD and C Red No. 3) in a V79 hepatocyte-mediated mutation assay. Mutat Res. 1988; 205(1-4): 415-423. [CrossRef]

[25] Borzelleca JF, Capen CC, Hallagan JB. Lifetime toxicity/carcinogenicity study of FD \& C Red No. 3 (erythrosine) in rats. Food Chem Toxicol. 1987; 25(10): 723-733. [CrossRef]

[26] Abdel Aziz AH, Shouman SA, Attia AS, Saad SF. A study on the reproductive toxicity of erythrosine in male mice. Pharmacol Res. 1997; 35(5): 457-462. [CrossRef]

[27] Vivekanandhi J, Anitha Devi CP, Jayaraman K, Raghavan L. Effects of erythrosine on testicular function of mice. Toxicol. Int. 2006; 13(2): 119-125.

[28] Zhong Z, Li G, Luo Z, Zhu B. Microwave-assisted dispersive liquid-liquid microextraction coupling to solidification of floating organic droplet for colorants analysis in selected cosmetics by liquid chromatography. Talanta. 2019; 194: 46-54. [CrossRef]

[29] Adlnasab L, Ezoddin M, Karimi MA, Hatamikia N. MCM-41@Cu-Fe-LDH magnetic nanoparticles modified with 
cationic surfactant for removal of Alizarin Yellow from water samples and its determination with HPLC. Res Chem Intermed. 2018; 44(5): 3249-3265. [CrossRef]

[30] Mijin DŽ, Tomić VD, Grgur BN. Electrochemical decolorization of the Reactive Orange 16 dye using a dimensionally stable Ti/PtOx anode. J. Serb. Chem. Soc. 2015; 80(7): 903-915. [CrossRef]

[31] Sadeghi S, Nasehi Z. Simultaneous determination of Brilliant Green and Crystal Violet dyes in fish and water samples with dispersive liquid-liquid micro-extraction using ionic liquid followed by zero crossing first derivative spectrophotometric analysis method. Spectrochim Acta A Mol Biomol Spectrosc. 2018; 201: 134-142. [CrossRef]

[32] Watanabe T, Terabe S. Analysis of natural food pigments by capillary electrophoresis. J Chromatogr A. 2000; 880(12): 311-322. [CrossRef]

[33] Huang HY, Shih YC, Chen YC. Determining eight colorants in milk beverages by capillary electrophoresis. J Chromatogr A. 2002; 959(1-2): 317-325. [CrossRef]

[34] Yoon J, Kim Y, Kim KB, Park EJ, Na DH. Reversed-phase high-performance liquid chromatographic method for the determination of permaton red (D\&C Red No. 36) in cosmetics. Bull Korean Chem Soc. 2018; 39(10): 1219-1222. [CrossRef]

[35] Brazeau J. Identification and quantitation of water-soluble synthetic colors in foods by liquid chromatography/ultraviolet-visible method development and validation. ACS Omega. 2018; 3: 6577-6586. [CrossRef]

[36] Heidarizadi E, Tabaraki R. Simultaneous spectrophotometric determination of synthetic dyes in food samples after cloud point extraction using multiple response optimizations. Talanta. 2016; 148: 237-246. [CrossRef]

[37] López- de- Alba, P. , López- Martínez, L. and De- León- Rodríguez, L. Simultaneous determination of synthetic dyes tartrazine, allura red and sunset yellow by differential pulse polarography and partial least squares. A multivariate calibration method. Electroanalysis. 2002; 14(3): 197-205. [CrossRef]

[38] Florian M, Yamanaka H, Carneiro PA, Valnice Boldrin Zanoni M. Determination of brilliant blue FCF in the presence and absence of erythrosine and quinoline yellow food colours by cathodic stripping voltammetry. Food Addit Contam. 2002; 19(9): 803-809. [CrossRef]

[39] Pochivalov A, Davletbaeva P, Cherkashina K, Lezov A, Vakh C, Bulatov A. Surfactant-mediated microextraction approach using switchable hydrophilicity solvent: HPLC-UV determination of Sudan dyes in solid food samples. J Mol Liq. 2018; 271: 807-814. [CrossRef]

[40] Weisz A, Milstein SR, Scher AL. Colouring agents in cosmetic products (Excluding hair dyes): Regulatory aspects and analytical methods. In: Salvador A, Chisvert A. (Eds). Analysis of cosmetic products. Elsevier, Oxford, 2007, pp.153-189. [CrossRef]

[41] International Conference on Harmonisation (ICH). In: Q2 (R1) Validation of analytical procedures: text and methodology. Geneva, 2005.

This is an open access article which is publicly available on our journal's website under Institutional Repository at http://dspace.marmara.edu.tr. 